\title{
Viewpoint: The role of drought in range management
}

\author{
THOMAS L. THUROW AND CHARLES A. TAYLOR, JR.
}

Authors are professor and head, Renewable Resources Department, University of Wyoming, Laramie, Wyo. 82071 and professor, Texas Agriculture Experiment Station, P.O. Box 918, Sonora, Tex. 76950.

\begin{abstract}
Drought is an ambiguous term, subject to expectation and the weight of emphasis on meteorological, agricultural, hydrological and socio-economic dimensions. Uncertainty associated with the identification of drought often results in a lagged response in reducing stocking rates. This delay reduces vegetation cover, increasing the potential for accelerated erosion following the drought. The long-term consequences of accelerated erosion are a reduction of soil depth, a decline in soil structure and a decrease in infiltration rate and water storage capacity. Less water stored on a site hastens the onset of plant stress, effectively increasing the perceived frequency and consequences of drought. Management and policy tools must improve the integration of economic and ecological aspects of drought-induced de-stocking decisions, especially by incorporating the long-term irreversible costs of erosion.
\end{abstract}

Key Words: climate, desertification, erosion, grazing management, hydrologic cycle

Drought is a multi-faceted concept which defies attempts at precise and objective definition. This ambiguity causes confusion and indecision, resulting in either inaction or ad hoc responses which do not fully consider the complex, long-term ecological and socio-economic interactions associated with water shortages (Wilhite and Glantz 1985). The media and politicians tend to blur and distort public perceptions of drought by characterizing the consequences of drought as something exceptional, thereby portraying drought as a temporary, climatic aberration. Consequently, each time a serious drought occurs, millions of words are written about crop failures, land misuse, overpopulation, and rainfall record (Tannehill 1947), but because drought is often handled in the policy arena as an abnormal event, it usually is not taken seriously in planning once expected rainfall patterns resume. Drought is an inevitable part of normal climate fluctuation and should be considered as a recurring, albeit unpredictable, environmental feature which must be included in planning. Muddled views and lagged responses toward drought pose a threat to sustainable management of rangelands.

Authors wish to thank A.P. Thurow for her comments on the manuscript.

Manuscript accepted 29 Nov. 1998.

\section{Resumen}

La sequía es un término ambiguo, depende de las condiciones esperadas y del énfasis en las dimensiones metereológicas, agrícolas, hidrológicas y socioeconómicas. La incertidumbre asociada con la identificacion de sequías resulta frecuentemente en una respuesta tardía en la reducción de la carga animal. Este retraso reduce la cubierta vegetal, aumentando el potencial de una erosión acelerada después de la sequía. Las consecuencias a largo plazo de la erosión acelerada son la reducción de la profundidad del suelo, el deterioro dela estructura del suelo, y la reducción de la tasa de infiltración y de la capacidad de almacenamiento de agua. La reducción del volumen de agua almacenada en un sitio acelera el inicio de stress en la planta, incrementando efectivamente la percepci ón sobre la frecuencia y las consecuencias de las sequías. Las pol ticas y estrategias de manejo deben mejorar la integración de los aspectos económicos y ecológicos de la reducción de la carga animal inducida por la sequía, especialmente incorporando los costos irreversibles y a largo plazo de la erosión.

\section{Perspectives on the Definition of Drought}

Much of the confusion about drought results from various perspectives of how to define it. The beginning and end of a drought are hard to recognize because drought is a gradual phenomenon. The effects of drought often accumulate slowly as a dry period begins and may linger after expected rainfall patterns have resumed. Most drought definitions are based on 1) meteorological observations, 2) agricultural problems, 3) hydrological conditions and/or 4) socioeconomic considerations (Wilhite and Glantz 1985). Perception of drought, therefore, depends on how the nuances of these 4 perspectives are blended.

\section{Meteorological Drought Perspective}

Most interpretations of drought have a meteorological element as part of the definition. This perspective refers to a significant decrease from the climatologically-expected precipitation. Expectations vary with location and are often site specific. For example, a drought in Bali, Indonesia is defined as a period of 6 days without rain while, at the other extreme, a drought in parts of Libya is identified only after 2 years without rain (Hudson and Hazen 1964). The Society of Range Management Glossary (Kothmann 1974) uses a meteorologi- 
cal-based definition of "prolonged dry weather, generally when precipitation is less than three-quarters of the average annual amount." The Palmer Drought Severity Index (PDSI) (Palmer 1965) is probably the best known meteorologic drought definition in the United States. It relates drought severity to the accumulated weighted differences between precipitation and evapotranspiration (ET).

A common criticism of meteorological criteria to define drought centers on the basis for the calculation of "normal" (Glantz and Katz 1977). By international convention, a 30-year precipitation record generally is considered the basis for a calculation of "normal" (Wilhite and Glantz 1985). This practice does not make use of the entire historical precipitation record available for many locations; therefore it may not adequately reflect the long-term climatic record, especially in semi-arid regions prone to large interannual variation.

Use of the term "normal" is also undermined by a common statistical mistake. Often "normal" is calculated as the arithmetic mean. An arithmetic mean (i.e., summing annual precipitation data and than dividing by the number of years) is not a statistically valid technique for representing "normal" when the data do not have a bell-shaped (parametric) distribution. Improper application of the arithmetic mean calculation may result in annual precipitation being below "average" most of the time. Annual precipitation data are usually highly skewed (e.g., many dry years and a few very wet years). The degree of skewness generally increases as the climate becomes drier (Glantz and Katz 1977). This occurs because occasional meteorologic conditions produce unusually heavy rainfall for a few years of the record. For example, an "El Niño" shift in ocean current results in substantial rains in otherwise arid regions in central Chile, northern Mexico and the southwestern US (Rasmusson 1987, Hunt 1991).

When long-term precipitation data are skewed, as they are for many arid and semi-arid rangelands, a statistically appropriate method for expressing "normal" precipitation is to calculate the median (i.e., the mid-point of the data set, where half of the years are wetter and half are drier than the median value) or the mode (i.e., the amount of precipitation most likely to occur). Neither of these measures are particularly sensitive to skewness and their interpretations are explicit.
Due to the unstable nature and complexity of atmospheric dynamics, the theoretical limit of accurate weather prediction does not exceed a few weeks (Skukla 1985). Much attention has been devoted to searching for trends or cycles of long-term climate; discussion of this issue in the popular press ignores the important aspect of rainfall on many rangelands-its extreme variability. Even if trends or cycles do exist, the inherent variability of seasonal forecasts limit their managerial value (Glantz and Katz 1977, Rasmusson 1987).

\section{Agricultural Drought Perspective}

Many identify drought in terms of when water deficits limit vegetation production. From an agricultural perspective a drought occurs when low soil moisture causes extreme plant stress and wilt, and lowers grain yield (Carr 1966) or results in less forage production than expected. This definition is more complicated than simple considerations about the amount of precipitation. By definition it integrates the timing and amount of precipitation with plant water demand (as can be influenced by high temperatures and wind) and available soil water (as can be influenced by the infiltration capacity, soil texture, and soil depth). These considerations led Palmer (1968) to develop the Crop Moisture Index (CMI). The CMI modifies the meteorologically-based Palmer drought severity index (PDSI) to better reflect the considerations of agricultural drought by emphasizing the deficit between actual and expected weekly evapotranspiration (ET). This index is available for the U.S. in the Weekly Weather and Crop Bulletin, published jointly by the U.S. Department of Agriculture and the National Weather Service.

There are a variety of species-specific drought indices designed to analyze various aspects of water supply and demand needed for important agronomic species (cf., Meyer et al. 1993). These indices, based on crop models, tend to characterize drought intensity by emphasizing available water in the topsoil required to meet plant water demand. This rationale considers the amount of water in the topsoil as a critical element of drought calculation because of the interaction of water with root growth, nutrient supplies, and microorganism activity which occur in that zone. Drying of the topsoil layer, therefore, is considered an early indicator of yield loss. These types of speciesspecific indices are rarely calculated for native forage species, but intercepted photosynthetically active radiation (IPAR) data collected by satellites are increasingly being used to identify regional drought on rangeland. Estimates of IPAR can indicate drought severity by contrasting a region's yearly relative difference of photosynthetic capacity (Tucker and Goward 1987).

\section{Hydrologic Drought Perspective}

A hydrologic drought is defined as a period when surface and groundwater availability is inadequate to supply established uses (Linsley et al. 1975). Therefore, this definition of drought focuses attention on the drying of streams and rivers, depletion of water stored in surface reservoirs and lakes, lower than normal accumulation of snowpack in the mountains, and decline of ground water levels. This concept of drought is often used by regional planners who are concerned with amenities such as municipal and/or irrigation water supply, hydro-electric power generation, and recreational opportunities. This perspective may also be used by a rancher who identifies drought as when a particular pond or stream dries up.

\section{Socio-economic Drought \\ Perspective}

Not all water shortages are manifest in ways that impact people. A socio-economic perspective does not recognize drought until it tangibly effects peoples' lives in terms of their behavior and options (e.g., water rationing, increased prices, or lost recreational opportunities) or depressed earning power (in particular reduced agricultural income which may effect the viability of the individual enterprise and, if severe enough, may trickle down and adversely affect through other industries, thus increasing regional financial stress).

\section{Drought Perspective Complications}

These 4 perspectives-meteorological, agricultural, hydrologic, and socioeconomic - are frequently out of phase; therefore, contradictory statements in 
discussions about drought are not surprising. Differing definitions and perspectives result in confusion and make it difficult for people with diverse interests to agree about what a drought is, when it begins, and when it ends. Meteorologic drought is not directly tied to agricultural drought because other factors-such as temperature, wind, infiltration rate, soil moisture storage capability, timing of rain relative to plant growth needsare not accounted for in the definition of meteorologic drought, but do make a difference in the perception and consequences of agricultural drought. The beginning and end of a hydrologic drought, especially when viewed in terms of large reservoir or aquifer management, tends to lag far behind meteorologic drought. Also, depending on the recharge system, hydrologic drought is less closely associated with total amount of precipitation than to episodic large events which generate significant runoff or deep drainage. Thus, a single highintensity thunderstorm may produce a flash-flood that fills reservoirs and exceeds the monthly precipitation average, but does little to alleviate a water shortage for terrestrial vegetation. Conversely, a series of light showers may result in lush plant growth, but not recharge streams and aquifers.

The socio-economic elements of drought are especially complicated because there is a human expectation element involved that may or may not be realistic. For example, the demand for water may be impossible to fulfill when regional economic development expands demand beyond typically available supplies. Thus, water availability during a dry period might not be recognized as drought in sparsely settled areas, but could result in serious water shortages if a large urban population were present. Likewise, a pastoralist who grazes a cattle herd may experience the consequences of drought sooner and more frequently than a pastoralist herding camels.

The socio-economic ripple-effects (secondary impacts) initiated by a water shortage make it very difficult for diverse stakeholders to agree about when the consequences of a drought have ended (Kulshreshtha and Klein 1989). For example, a water shortage that reduces crop and fodder growth may force ranchers to sell their livestock. Once livestock are sold, it may take several years to build herds back to their original pre-drought level. Ultimately, a reduction in income may lead to the financial demise of some enterprises, contributing to migration out of the region. For example, about 250,000 people who had settled on the U.S. prairies during the high rainfall years early in the century left their homesteads during the 1930's drought, never to return (McKay 1980).

\section{The Drought Paradox}

A common worldwide assertion by users of degraded rangeland is that droughts are more frequent and more severe than during previous generations. However, there is usually no discernable difference in the long-term trend of the amount and temporal distribution of precipitation and/or temperature. How can these seemingly contradictory observations be reconciled?

Despite no widespread conclusive evidence that "meteorological" droughts are increasing, a history of unsustainable range use causes an increase in the frequency and consequences of drought defined from an "agriculture perspective". The increase in "agricultural" drought is attributable to erosion, crusting, and/or degraded vegetation.

\section{Erosion}

Semi-arid rangelands are highly susceptible to erosion (Marshall 1973, Mannering 1981). This is because wet environments have sufficient rainfall to support a natural vegetation cover capable of protecting the soil from the erosive energy of wind and water; and arid environments generally have insufficient rainfall and runoff to transport large quantities of sediment. In semiarid regions, extreme or intense precipitation events do occur which can transport large quantities of sediment, yet cover needed to protect the soil from wind and water erosion is not complete. The erosion hazard during a drought is increased when prolonged grazing pressure has further reduced plant cover. Wind velocity, and its potential to detach and transport dry soil, exponentially increases near the ground as vegetation's sheltering effect is reduced (Marshall 1973). Substantial nutrient loss is often associated with wind ero- sion. For example, Bennett (1939) found that the organic matter and nitrogen content of soil suspended by wind was 3 times greater than in the soil left behind.

For many western U.S. rangelands, an erosion rate of about $1 \mathrm{~mm} \mathrm{yr}^{-1}$ (approximately 11 tons $\left.\mathrm{ha}^{-1} \mathrm{yr}^{-1}\right)$ is considered an "acceptable" soil loss rate (Mannering 1981). This interpretation of "acceptable" is at odds with the very slow rate of soil formation on rangelands, which is usually much less than the $0.1 \mathrm{~mm} \mathrm{yr}^{-1}$ rate of soil formation estimate for cropland (Pimental et al. 1976, Pimental et al. 1995). Part of the reason for the discrepancy between soil formation and erosion rates is that "acceptable" is a subjective term that is influenced by the extent of the planning horizon (e.g., planning to maintain production potential for a 50 year period results in a quite different "acceptable" erosion rate than if planning over a 500 year horizon). Due to the long-term loss of soil depth and its associated decline in water storage potential, adoption of a zero-level accelerated erosion standard for rangelands has been recommended as a management criterion which aims to maintain and enhance site productivity (Mannering 1981). Accelerated erosion is soil loss caused by human land use decisions, as contrasted with natural or geologic erosion which occurs independent of human activities.

The danger of rangeland use resulting in accelerated erosion that would threaten long-term sustainability was addressed by the Society for Range Management Task Group on Unit in Concepts and Terminology (1995) which recognized that sustainability (the fundamental goal of rangeland management) depends primarily on conservation of the soil. This group concluded that erosion was a function of protective attributes (e.g., cover, biomass, density of plants), therefore use of the rangeland should not contribute to reducing the protective attributes of vegetation below a level identified as the Site Conservation Threshold (SCT) (i.e., the point beyond which vegetation is unable to hold the soil in place).

On rangelands where accelerated erosion is occurring, the gradual decrease in soil depth translates into a loss of soil moisture storage capability which, in turn, can increase both the frequency and length of periods without enough soil moisture for expected plant growth. As a 
site becomes increasingly vulnerable to agricultural drought, the difficulty in maintaining plant cover increases and the site becomes more vulnerable to accelerated erosion, which creates a spiral of decreasing production potential (Thurow 1991, Le Houérou 1996). Indeed, one definition of desertification is the diminution or destruction of biological production potential (Dregne 1987), a characterization that is not specifically linked to precipitation. Therefore, even though precipitation patterns do not change, a site can lose production potential by losing soil which reduces the nutrients and moisture storage capability of the site.

\section{Crusting}

Another problem associated with a site's vegetation cover dropping below the site conservation threshold (SCT) is that the exposed soil has an increased susceptibility to crusting. When rain strikes exposed soil the particles are detached by the raindrop energy and are likely to lodge in the remaining soil pores, making them smaller or sealing them completely (Lynch and Bragg 1985). This is one way in which soil crusts are formed. A "washed in" layer of clay particles that clogs soil pores and forms a crust may reduce infiltration rates by up to $90 \%$ (Boyle et al. 1989).

An increase in grazing intensity is sometimes advocated as a stop-gap measure intended to increase infiltration (OTA 1982). Livestock trampling does break soil crusts and incorporate mulch and seeds into the soil; however, this prescription is not a solution since any increase in infiltration is short-lived because the raindrop impact quickly reseals the soil surface as the unstable soil pores become plugged. The potential for wind erosion also increases when the soil has been churned to dust. The only solution to crusted soils is to eventually accumulate enough cover so that rainfall energy is dissipated before it reaches the soil. Building back the cover may be a very slow process; like with many aspects of degradation, it is much easier to avoid getting into the problem than trying to fix it.

\section{Degraded vegetation}

Many perceived agricultural droughts are related to forage shortages which should be recognized as carrying capaci- ty crises caused by inappropriate stocking policies (Robinson 1982, Dankwerts and King 1984). Numerous studies support the general conclusion that there are no significant differences in infiltration rates or soil loss between similar ungrazed and moderately grazed rangelands (cf., Thurow 1991). However, heavy grazing results in reduced infiltration and accelerated erosion. The quandary is that moderate grazing rates are, in practice, calculated on the basis of expected production from a site. During an agricultural drought, the physiological needs of forage plants are not met and production rapidly declines. The result is that rangelands stocked at a moderate rate based on long-term experience may actually be heavily stocked based on physiological condition of plants during a dry period. Physiological stress may occur more quickly if the vegetation has low energy reserves as a result of having been subjected to intense grazing pressure prior to a dry period. The amount, vigor, and quality of vegetation is correlated with the condition of the range. Therefore, agricultural drought on sites in poor condition is likely to be manifest more frequently and more severely than on sites in good condition.

Figure 1 illustrates the decline in the stocking rate on the Texas Agriculture

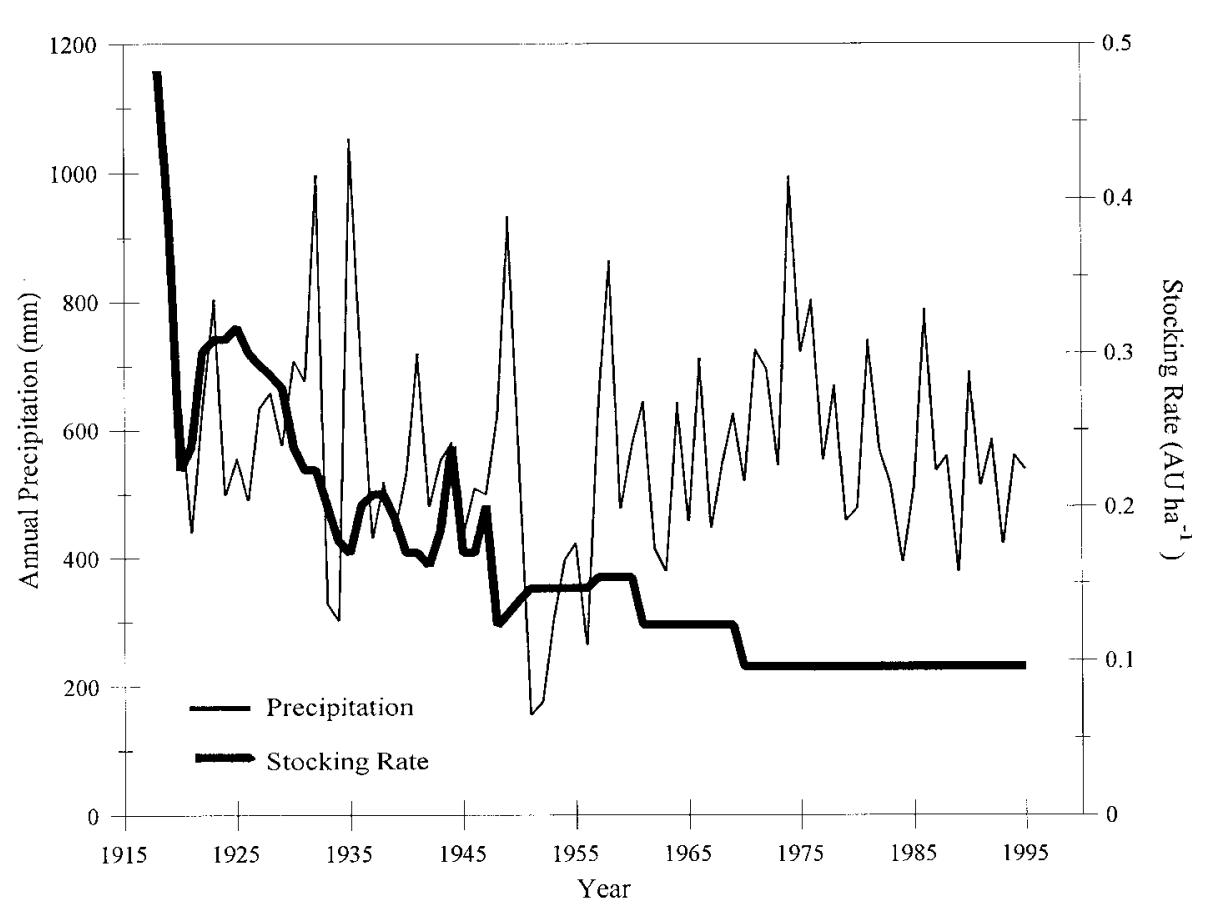

Fig. 1. Stocking rate and precipitation records for the Texas A\&M University Sonora Research Station.
Experiment Station at Sonora since the site was obtained by the State in 1916. Throughout this period, managers of the ranch considered it to be moderately stocked. Productivity has demonstrably declined to the point that it would now by physically impossible to keep the same number of livestock alive (much less in productive condition) on the same rangeland that once supported higher stocking rates for decades. Two factors have probably contributed to this condition. One is an increase of low palatability woody shrubs which have a high water use potential (e.g., Juniperus pinchotti Sudw.) (Smeins et al. 1997). and another is erosion of the shallow ( $\sim 25$ $\mathrm{cm}$ ) silty-clay (overlying a fractured limestock substrate) which has reduced the site's water-holding capacity. Indeed, it is a common assertion in the region that frequency of drought is increasing and carrying capacity is decreasing, even though no statistical difference in the monthly or annual precipitation or temperature has occurred. The degree to which the decrease in stocking rate and perception of drought are attributable to reduced soil moisture storage capability is complicated by the fact that erosion and infiltration are related to composition shifts in vegetation cover which 
may be less palatable to livestock and/or increase the rate of evapotranspiration loss from the site (Thurow et all 1986, Thurow and Hester 1997).

In extreme cases of widespread rangeland degradation, a severe reduction of vegetation cover can change surface reflectivity, which can theoretically inhibit cloud formation and reduce precipitation (Charney et al. 1975, Otterman 1977). For managers to prevent accelerated erosion and possible alteration of local climate, their management system must be able to respond to reduced vegetative growth quickly, so that adequate plant and litter cover remain (i.e., so that the SCT is not crossed).

\section{The Role of Government in Drought Response}

Lowdermilk's (1953) classic review of civilization and natural resource use concluded that preservation of the soil resource and associated hydrologic conditions are essential to a society's wellbeing. Lowdermilk cautioned that history illustrates how decisions made for short-term economic and political reasons are the root cause of long-term degradation. Such concerns are especially manifest when the long-term threat of erosion is pushed to the background in response to short-term pain associated with a drought. Placing erosion control as top priority in such circumstances is unlikely because this issue for politicians "is thorny, it is packed with political dynamite, and it will always keep for another couple of years" (Huxley 1937).

Droughts are a natural part of climate and are certain to occur; therefore, droughts should be expected. It is disingenuous to use the unpredictability of drought as an excuse for inadequate planning decisions that have failed to take rainfall variability into account! Exposing the land to accelerated erosion hazard should be viewed as a managerial failure, instead of making drought a scapegoat for faulty policies.

One reason that policy-makers and landowners persist in treating drought as a quirk of nature is that if they accept the challenge of planning for drought, then they implicitly accept the responsibilities associated with the development and implementation of proactive responses to drought. These are difficult responsibili- ties to bear because the costs of planning for drought are fixed and occur now while the costs of degradation from drought are uncertain and occur later.

Due to a general failure to include drought as part of the policy formulation process, "post-drought assessments and evaluations have generally shown governmental response to drought is largely ineffective, poorly coordinated, untimely and economically inefficient" (Wilhite 1987). An example of the negative impacts of governmental responses to drought on rangelands is the USDA-FSA Emergency Feed Program which has recently been phased out and is being replaced with the Non-Insured Assistance Program. These kinds of programs, by any name, enable ranchers to stock at higher rates than would be prudent if they were vulnerable to the full downside risk associated with drought.

"Moral hazard" is a term used to describe a policy that encourages reckless behavior because the participants know they will be buffered from negative consequences (Fleisher 1990). Feed assistance programs create a moral hazard because a rancher is positioned to benefit from maintaining a high stocking rate if the rains resume and the government reduces or eliminates the potential for short-term financial losses if the drought continues. Pastoralists in countries with governments unlikely to intervene with financial aid are typically conservative and risk averse. The example of an acrobat who is much less daring when there is no safety net illustrates that behavior changes as a function of available risk protection. Knowing that the government will provide a feed subsidy "safety net" during drought makes non-sustainable stocking rates appear more profitable than lower stocking rates in the short-term (Holechek and Hess 1995). These types of feed subsidy programs undercut the linkage between ecology and economics.

Ironically, government programs to provide "drought relief" feed subsidies enable managers to retain livestock on rangelands longer into a drought, thereby increasing the potential for degradation of the soil and vegetation resource which will actually increase the frequency and consequences of an agriculture drought. Rather than subsidize feed, government policies should focus on providing incentives for early destocking in response to dry conditions. Incentives geared to facilitating early destocking would be especially helpful in moderating damage to leased lands. This is because lease fees tend to be based on a land unit, instead of a per-head basis. Under these conditions, the leasee tends to have a low equity position in livestock and may not be able to sell them without being forced into bankruptcy.

If politicians remain intent on providing feed subsidies, access should be combined with a requirement that ranchers tangibly demonstrate that they are practicing effective grazing and business management. This could be accomplished by requiring that ranchers implement a drought response strategy, preapproved by an organization such as the USDA-NRCS, as soon as forage production begins to lag behind expectations. Qualification for subsidies would be limited to ranchers who receive preapproval for their plan and document that they were implementing the plan. Rancher-targeted courses in grazing and financial management would help in the development of ranch-specific drought response plans. In this way government programs would serve mostly as sources of information that will help to reduce environmental and financial risk. Such programming may be considered over obtrusive by some, but the program would be voluntary and would reward good stewardship instead of poor management. The key is that accountability for sound environmental management be built into a feed subsidy program.

Another consideration for governmentsponsored drought relief would be the initiation of a long-term easement program, similar to the Conservation Reserve Program (CRP), designed to facilitate resting rangeland in an area designated as being affected by drought. Under such a program a rancher would receive payments for removing livestock for the duration of the drought and for a specified period thereafter. Historically, it has taken a region months or years for herds to recover to pre-drought levels. Gradual re-stocking gave range plants a chance to recover once the rains resumed. Such a scenario is no longer likely, especially since improved transportation networks and the North American Free Trade Agreement (NAFTA) has expanded the area from which to draw livestock to rapidly restock rangeland. 


\section{The Role of the Rancher in Drought Response}

There will always be uncertainty (imperfect knowledge) regarding inherent climatic variability, market prices, and external financial considerations such as interest rates. Planning for drought must, therefore, focus on things that the manager can do to reduce risk (uncertain consequences) associated with climatic variability.

Devising a management strategy that emphasizes minimizing climatic and financial risk is a more sound approach to ranch management than attempting to maximize forage production and harvest efficiency (Holechek 1996). Ranches that employ intensive grazing systems geared to maximizing harvest efficiency often encounter a "feed-drought" sooner and more frequently than a ranch with lower harvest efficiency (Holechek 1993). Use of intensive grazing systems requires the rancher to promptly respond to deviations from expected forage supply. Such an expectation is simply not realistic for many ranchers since they do not have the labor availability, the mindset, or the ecological/financial expertise to implement this responsibility.

Modern technology and financial structures provide many self-evident benefits in terms of increasing efficiency and flexibility of rangeland use. However, this flexibility can be misapplied to enable ranchers to delay making de-stocking decisions. For example, the ability to procure loans for feed supplies can allow a rancher to retain livestock on the range past the point of rangeland carrying capacity. Development of wells provides a secure water source, thereby the natural controlling factor of drinking water availability is de-coupled from forage availability (Sandford 1983). As a result of the delay afforded by ranch improvements, decisions intended to reduce short-term losses can actually raise the stakes by increasing long-term economic and ecological risks, including the possibility for catastrophic damage (i.e., bankruptcy from an economic perspective and irreversible degradation from an ecological perspective), if the hoped-for rain does not occur.

In the absence of moral hazard behavior encouraged by subsidies, the economic optimum (maximum profit) stocking rate is almost always lower (and never higher) than the biological optimum (maximum sustained yield) (Workman 1986). It is therefore vital that the rancher maintain the proper stocking rate for any given weather/forage condition to minimize the consequences of drought. If ranchers aggressively implement tactical decisions of substantial destocking they will have better long-term expected economic return, with less variance, than if they engage in hopeful inaction (Stafford Smith and Foran 1992). This conclusion, based on an analysis of a sheep enterprise on the semi-arid rangelands of South Australia, showed that a policy of aggressive destocking when rain begins to lag behind expectation would have been the most economically rewarding and sustainable course of action, given commodity price responses and using weather records of the past century. Likewise, an analysis of arid zone beef cattle ranches in central Australia over the past century (Foran and Stafford Smith 1991) concludes that if no government support was available during dry years, then a low-stocking strategy was favored, but that availability of government support during drought made strategies with higher stocking more favorable.

It is the responsibility of the individual rancher to be aware of how much forage is available and to anticipate current and future animal (livestock and wildlife) demand. Monitoring the extent of use on key vegetation species is a useful indicator of grazing pressure. By careful monitoring and control of grazing, the rancher can quickly identify and respond to the beginning of a forage deficit. Userfriendly computer decision aids, such as The Grazing Manager (Kothmann and Hinnant 1992) or the Grazing Lands Application (GLA)/Resource System Planning Model (RSPM) Stuth et al. 1990) have been developed to help ranchers estimate seasonal adjustments of livestock stocking rates and test "what if" scenarios regarding rainfall. These tools provide the rancher with timely information to maintain a proper balance between forage production and animal demand, thus preventing damage to the range resource, limiting death losses of livestock due to consumption of poisonous plants (Taylor and Ralphs 1992) and avoiding the full vulnerability associated with market crashes that frequently accompany droughts. Adoption of a grazing strategy that provides a cushion of "reserve forage" provides ranchers some flexibility in the speed and extent to which they must respond to drought. Another reason that lower stocking rates are usually more desirable than seeking to maximize harvest efficiency is to allow for the periodic use of fire necessary to control brush encroachment (Taylor and Kothmann 1993).

The wait-and-see management style that characterizes the majority of rangeland use decisions in the face of drought has a high long-term cost, especially in terms of the irreversible costs of erosion. The downward spiral is self-perpetuating: as erosion occurs there is less soil moisture storage capability and more production vulnerability to inherently erratic precipitation patterns. Rather than blaming management problems on climate, the challenge to rangeland scientists and policy-makers is to intensify the research focus on crafting and implementing management and policy tools designed to better integrate the economic and ecological aspects of droughtinduced de-stocking decisions.

\section{Literature Cited}

Bennett, H.H. 1939. Soil conservation. McGraw-Hill, New York, N.Y.

Boyle, M., W.T. Frankenberger, Jr., and L.H. Stolzy. 1989. The influence of organic matter on soil aggregation and water infiltration. J. Prod. Agr. 2:290-299.

Carr, J.T. 1966. Texas droughts, causes classification and prediction. Report No. 30. Texas Water Development Board, Aust, Tex.

Charney, J., P.H. Stone, and W.J. Quirk. 1975. Drought in the Sahara: a biophysical feedback mechanism. Sci. 187:434-435.

Dankwerts, J.E. and P.G. King. 1984. Conservative stocking or maximum profit: A grazing management dilemma. J. Grassl. Soc. So. Africa. 1:25-28.

Dregne, H.E. 1987. Reflections of the U.N. plan of action to combat desertification. Desertification Control Bull. 15:8-11.

Fleisher, B. 1990. Agricultural Risk Management. Lynn Rienner Publ. Boulder, Colo.

Foran, B.D. and D.M. Stafford Smith. 1991. Risk, biology and drought management strategies for cattle stations in Central Australia. J. Environ. Manage. 33:17-33.

Glantz, M.H. and R.W. Katz. 1977. When is a drought a drought? Nature. 267:192-193. 
Holechek, J.L. 1993. Managing stocking rates to achieve range resources goals. $\mathrm{p}$. 10-25. In: J.R. Cox (ed.), Managing Livestock Stocking Rates on Rangeland. Department of Rangeland Ecology and Management and Texas Agricultural Extension Service, College Station, Tex.

Holechek, J.L. 1996. Drought in New Mexico: Prospects and management. Rangelands 18:225-227.

Holechek, J.L. and K. Hess, Jr. 1995. Government policy influences on rangeland conditions in the United States: A case example. Environ. Monitoring and Assessment 37:179-187.

Hudson, H.E. and R. Hazen. 1964. Drought and low stream flow. 18:1-26. In: V.T. Chow (ed.), Handbook of applied hydrology. McGraw-Hill, New York, N.Y.

Hunt, B.G. 1991. The simulation and prediction of drought. Vegetatio. 91:89-103.

Huxley, E. 1937. The menace of soil erosion. J. Royal African Soc. 36:365-370.

Kothmann, M.M. 1974. A glossary of terms used in range management. Soc. Range Manage., Denver, Colo.

Kothmann, M.M. and R.T. Hinnant. 1994. The grazing manager Version 1.0. Texas Agr. Exp. Sta. Software Manual. College Station, Tex.

Kulshreshtha, S.N. and K.K. Klein. 1989. Agricultural drought impact evaluation model: a systems approach. Agr. Sys. 30:81-96.

Le Houérou, H.N. 1996. Climate change, drought and desertification. J. Arid Environ. 34:133-185.

Linsley, R.K. Jr., M.A. Kohler, and J.L.H. Paulhus. 1975. Hydrology for engineers. McGraw-Hill, New York, N.Y.

Lowdermilk, W.C. 1953. Conquest of the land through 7,000 years. USDA-SCS, Agr. Info. Bull. No. 99.

Lynch, J.M. and E. Bragg. 1985. Microorganisms and soil aggregate stability. Adv. Soil Sci. 2:133-171.

Mannering, J.V. 1981. The use of soil loss tolerances as a strategy for soil conservation. p. 337-349. In: R.P.C. Morgan (ed.). Soil conservation: problems and prospects. John Wiley \& Sons, New York, N.Y.

Marshall, J.K. 1973. Drought, land use and soil erosion. p. 55-77. In: J.V. Lovett (ed.). The environmental, economic and social significance of drought. Angus and Robertson, Publ. Sydney, Australia.

McKay, G. 1980. Mitigation of the effects of drought with special reference to the Canadian experience. p. 88-95. In: N.J. Rosenberg (ed.) Drought in the Great Plains: Research on impacts and strategies. Water Resources Publ. Littleton, Colo.

Meyer, S.J., K.G. Hubbard, and D.A. Wilhite. 1993. A crop-specific drought index for corn: II. Application in drought monitoring and assessment. Agron. J. 85:396-399.
Officer of Technology Assessment. 1982. Impacts of technology on U.S. cropland and rangeland productivity. U.S. Congr. Rep.

Otterman, J. 1977. Anthropogenic impact on the albedo of the earth. Climatic Change. 1:2.

Palmer, W.C. 1965. Meteorological drought. Res. Pap. No. 45. U.S. Weather Bur., Wash., D.C.

Palmer, W.C. 1968. Keeping track of crop moisture conditions nationwide: The new crop moisture index. Weatherwise 21:156-161.

Pimental, D., E.C. Terhune, R. DysonHudson, and S. Rocherau. 1976. Land degradation: Effects on food and energy resources. Sci. 94:149-155.

Pimental, D., C. Harvey, P. Resosudarmo, K. Sinclair, D. Kurz, M. McNair, S. Crist, L. Shpritz, L. Fitton, R. Saffouri, and R. Blair. 1995. Environmental and economic costs of soil erosion and conservation benefits. Sci. 267:1117-1122.

Rasmusson, E.M. 1987. Global prospects for the prediction of drought: A meteorological perspective. p. 31-44. In: D.A. Wilhite and W.E. Easterling (eds.). Planning for drought: Toward a reduction of societal vulnerability. Westview Press, Inc. Boulder, Colo.

Robinson, I.B. 1982. Drought relief schemes for the pastoral zone. Australian Rangeland J. 4:67-77.

Sandford, S. 1983. Management of pastoral development in the Third World. John Wiley \& Sons, Chinchester, U.K.

Skukla, J. 1985. Predictability. pp. 87-122. In: S. Manabe (ed.) Issues in atmospheric and oceanic modeling Part B: Weather dynamics. Acad. Press, New York, N.Y.

Smeins, F., S. Fuhlendorf, and C. Taylor, Jr. 1997. Environmental and land use changes: a long-term perspective. p. 1:3-21. In: C.A. Taylor, Jr., (ed.). Juniper Symposium Proceedings. Texas Agricultural Experiment Station TR 97-1. Sonora, Tex.

Society for Range Management Task Group in Concepts and Terminology. 1995. New concepts for assessment of rangeland condition. J. Range Manage. 48:271-282.

Stafford, Smith, M. and B. Foran. 1992. An approach to assessing the economic risk of different drought management tactics on a South Australian pastoral sheep station. Agr. Sys. 39:83-105.

Stuth, J.W., J.R. Conner, W.T. Hamilton, D.A. Riegel, B. Lyons, B. Myrick, and M. Couch. 1990. RSPM-A resource system planning model for integrated resource management. J. Biogeography. 17:531-540.

Tannehill, I.R. 1947. Drought: Its causes and effects. Princeton University Press, Princeton, N.J.

Taylor, C.A. Jr. and M.M. Kothmann. 1993. Managing stocking rates to achieve livestock production goals on the Edwards
Plateau. p. 42-52. In: J.R. Cox (ed.) Managing Livestock Stocking Rates on Rangeland. Dept. of Rangeland Ecol. and Manage. and Texas Agr. Ext. Serv. College Station, Tex.

Taylor, C.A. Jr. and M.M. Ralphs. 1992. Reducing livestock losses from poisonous plants through grazing management. J. Range Manage. 45:9-12.

Thurow, T.L. 1991. Hydrology and erosion. pp. 141-159. In: R.K. Heitschmidt and J.W. Stuth (eds.), Grazing management: An ecological perspective. Timber Press. Portland, Ore.

Thurow, T.L. and J.W. Hester. 1997. How an increase or reduction cover alters rangeland hydrology. p. 4:9-22. In: C.A. Taylor, Jr., (ed.). Juniper Symposium Proceedings. Texas Agr. Exp. Sta. TR 97-1. Sonora, Tex.

Thurow, T.L., W.H. Blackburn, and C.A. Taylor, Jr. 1986. Hydrologic characteristics of vegetation types as affected by livestock grazing systems, Edwards Plateau, Texas J. Range Manage. 39:505-509.

Tucker, C.J. and S.N. Goward. 1987. Satellite remote sensing of drought conditions. p. 145-151. In: D.A. Wilhite and W.E. Easterling (eds.). Planning for drought: Toward a reduction of societal vulnerability. Westview Press, Boulder, Colo.

Wilhite, D.A. 1987. The role of government in planning for drought: Where do we go from here? p. 425-444. In: D.A. Wilhite and W.E. Easterling (eds.). Planning for drought: Toward a reduction of societal vulnerability. Westview Press, Inc. Boulder, Colo.

Wilhite, D.A. and M.H. Glantz. 1985. Understanding the drought phenomenon: the role of definitions. Water Int., 10:111-120.

Workman, J.P. 1986. Range Economics. Macmillan Publ. Co. New York, N.Y. 